TURIZAM

Volume 17 , Issue 4

166-176 (2013)

\title{
The Vital Components of Restaurant Quality that Affect Guest Satisfaction
}

Snježana Gagić*, Dragan Tešanović*, Ana Jovičić*

Received: September 2013 | Accepted: November 2013

\begin{abstract}
Nowadays, the trend of dining in restaurants has become quite prominent in Serbia. Frequent restaurant visits are not only the reflection of satisfying hedonistic needs, but also the result of increasing number of single-person households as well as adjustment to the European business hours.

In an increasingly competitive environment, restaurants must be focused on guests using marketing concepts that identify their needs thus leading to their satisfaction and increased retention.

Service quality is fundamental component which produce higher levels of guest satisfaction, which in turn lead to higher sales revenue.

The main purpose of this study was to examine the quality dimensions that affect guest satisfaction in restaurant industry. Food and beverage quality, the quality of service delivery, physical environment and price fairness are analyzed as a key components of restaurant experience.

The results could be helpful tool for restaurant managers to invest their resources more efficiently, making changes to crucial quality attributes that elicit the guests' satisfaction level. A management approach focused on guest satisfaction can improve restaurant business performance.
\end{abstract}

Key words: restaurant, quality, satisfaction, guests

\section{Introduction}

The restaurant industry is continuously growing worldwide. As the number of restaurants increase, people have many options for choosing a restaurant. When guests dine out at a restaurant, they cognitively evaluate what they experience. Among the potential candidates, perceived quality has been generally accepted as the foremost antecedent of customer satisfaction (Dabholkar et al., 2000). Like most service industries, the importance of perceived quality has been recognized in the restaurant industry as well (Oh, 200O).

In the restaurant industry, guests generally use food, physical environment, and employee services as key components of restaurant experience in evaluating the restaurant service

* University of Novi Sad, Faculty of Sciences, Department of Geography, Tourism and Hotel Management, Trg Dositeja Obradovića 3, 21000 Novi Sad, Serbia; Corresponding author: gagicsnjeza@yahoo.com. 
quality (Chow et al., 2007; Namkung and Jang, 2008). A proper combination of these vital attributes should result in guests' perceptions of high restaurant service quality, which in turn should enhance their satisfaction and loyalty.

It was confirmed by diverse researches that customer satisfaction is directly related to profitability of organization (Luo, Homburg, 2007). Improving the quality, as well as development of measures, act as preconditions for surviving modern market conditions and achieving successful business results (Blesic, Tesanovic, Psodorov, 2OIO).

Restaurants depend on the proper management whose education and training system is becoming increasingly important in order to meet the wants, needs and guests expectations, and thus ensure their satisfaction. Despite the importance of foodservice quality, managers know relatively little about how the combined effects of restaurant service quality (physical environment, food, and service) elicit restaurant image, guest perceived value, and satisfaction, which, in turn, affect guest behavior.

Restaurant guests decide upon the quality standards which are fulfilled, and managers who does not recognize this will experience decrease in volume of business and their clients will go to competition. Customer expectations are very important because, in case they are not met, guests will leave the premises quietly or spread negative rumors about the restaurant. With this in mind, it may be concluded that satisfaction is created by delivering additional values.

The paper aim was to investigate the factors affecting guest satisfaction in the restaurant industry as well as to show instruments designed to measure service quality in catering industry.

Building an inclusive view of quality as applicable to restaurants is a pressing concern because it will enable restaurant managers, within their limited resources, to prioritize decision-making that focuses on key quality attributes.

\section{Customer satisfaction and perceived quality}

Customer satisfaction is defined as a customer's overall evaluation of his or her purchase and consumption experience of a good or service (Johnson et al., I995). In addition, perceived quality refers to consumer's judgment about the performance of product or service (Zeithaml, 1987). Researchers in marketing generally agree that satisfaction and perceived quality are two of the most fundamental elements in effective service management (Rust, Oliver, 1994) as well as highly inter-related (Bitner, Hubbert, 1994).

Most research confirmed that customer satisfaction is directly related to profitability of organization (Luo, Homburg, 2007; Blesic, Tesanovic, Psodorov, 2OII; Martínez-tur, et al., 2OII) so it is important to identify all factors which affect it.

Taking into account heterogeneity of services in restaurant industry and personal dimension of their realization, it is extremely difficult to reach total customer satisfaction. Measurement of satisfaction enables finding out what is most important for users of services, learning how they perceive an organization and, eventually, defining priorities for improvement in order to increase customer satisfaction level and thereby profitability of an organization.

The nature of the relationship between customer satisfaction and service quality has received much attention in the services marketing literature. Because of the similarity between the two constructs, researchers have wondered whether service quality evaluation and customer satisfaction are identical (Iacobucci et al., I994). Satisfaction and perceived 
quality are highly inter-related because perceived quality is one of the core determinants of overall satisfaction. It is generally assumed that the key to gaining an advantage lies in delivering high-quality service that will, in turn, lead to satisfied customers (Han, Ryu, 2007).

\section{Instruments designed to measure service quality in catering industry}

From the review of literature on quality, it has been found that early research efforts concentrated on defining and measuring the quality in the manufacturing sector. Though systematic quality efforts started in the manufacturing sector in the I92Os, research in services started to grow in the late I97Os in several parts of the world (Gummesson, I99I). According to Zeithaml et al. (I990) service quality cannot be objectively measured as can manufactured goods and therefore it remains a relatively elusive and abstract construct. The evaluation of quality for services is more complex than for products because of their intrinsic nature of heterogeneity, inseparability of production and consumption, perishability and intangibility (Frochot and Hughes, 2000).

The Parasuraman, Zeithaml, and Berry study suggested that customers perceive service quality in terms of ten potentially overlapping dimensions. Subsequent analysis of the dimensions of service quality led to a five-factor model and accompanying scale, SERVQUAL, that has become the gold standard of service-quality measurement. SERQUAL is consisted of four intangible and one tangible construct. The intangible constructs include reliability (e.g., ability to perform the service accurately and dependably), responsiveness (e.g., willingness to help customers and provide prompt service), assurance (e.g., courtesy of employees and ability to create trust and confidence in customers), and empathy (e.g., caring, individual attention to customers). The tangibles construct addressed the physical facilities, equipment and appearance of personnel.

Nam and Lee (2OII) investigates the factors influencing foreign travelers' satisfaction with traditional Korean restaurants. Using a modified SERVQUAL scale, three dimensions of service quality ('intangibles', 'tangibles', and 'food') as well as expectation and value for money appear to positively influence them. Furthermore, foreign travelers' satisfaction has a positive influence on both their intention to revisit and their intention to recommend.

Today, there are numerous models that are used to improve the quality of service in the hospitality industry, including some exclusively created for restaurant industry.

Chronologically, following models were used: LODGSERV (Knutson et al., I99I), DINESERV (Stevens et al., I995), HOLSERV (Mei, Dean, \& White, I999), TANGSERV (Raajpoot, 2OO2) and DINESCAPE (Ryu \& Jang, 2OO8). The most used tools in restaurant industry utilized to define and measure service quality are DINESERV and DINESCAPE.

The LODGSERV is an instrument designed to measure service quality in the hotel industry. In this model five service quality dimensions emerged, among them "reliability" ranked first in hierarchy of importance for evaluating the service quality, followed by "assurance", "responsiveness", "tangibles", and "empathy".

Heung and Wong (1997) measured travellers' capectations of service quality for Hong Kong hotels and compared the service expectations of business and leisure visitors. They used LODGSERV instrument and found that 'Responsiveness' and 'Empathy' were more important to business travellers than leisure travellers. Mok and Patton (I999) used LODGSERV instrument for the measurement of hotel service quality expectations of Korean tourists. Surveys were conducted in South Korea during the summer of 1997. The results 
indicated that there was no significant difference in all expectation scores among guests of three different hotel categories: economy, mid-price, and luxury. Lockyer (2003) refined the LODGSERV model to include more specific items on cleanliness of the hotel lobby, guest room and bathroom.

The DINESERV is a model developed, also using SERVQUAL as a foundation. Despite all endeavors, one of the essential components of the restaurant experience, "food quality," was not included as part of the DINESERV measure. Hence, most quality studies in restaurant settings have concentrated on only a subset of quality, either atmospherics or employee services, but have not comprehensively examined all the vital components of restaurant quality. Thus, these quality studies may not have appropriately captured the idiosyncratic nature of the restaurant experience.

Kim, Ng and Kim (2OO9) investigate the relative importance of institutional DINESERV factors (i.e., food quality, atmosphere, service quality, convenience, and price and value) that affect customer satisfaction in the university dining facilities and examine the influence of customer satisfaction on return intention and word-of-mouth endorsement. The findings showed that all institutional DINESERV dimensions had a significant positive effect on overall customer satisfaction and revisit intention. Improving customer satisfaction, which results in increased return intention and positive word-of-mouth endorsement in university foodservice establishments, will in turn not only strengthen customer loyalty, but also improve the dining facility's reputation and generate greater revenue.

Ha and Jang (2OIO) showed that service and food quality have positive and significant effects on customer satisfaction and loyalty by using modified DINESERV model. This study found that good employee service can be more effective for increasing the satisfaction and loyalty of customers with a low perception of the atmospherics compared to those with a higher perception. Further, providing quality food is particularly critical for creating customer satisfaction in ethnic restaurants where atmospherics are not satisfactory.

According to Almanza et al. (I994) I7 attributes affecting customers' satisfaction in the university foodservice operation. Quality of food, cleanliness, convenient location, reasonable price, nutritious food, and speed of service were found to be important attributes for college students for a lunch meal in the university cafeteria.

Pettijohn et al., (1997) found that food quality was ranked as one of the most important determinants of a customer's decision to return in restaurant. Same results was obtaned by $\mathrm{Qu}$ (1997) and Matilla (2OOI). Food was significantly more important than cleanliness, value, price, and convenience. A study of fifteen, ambient theme restaurants in Hong Kong confirmed that service quality was a strong factor in customer revisit intention to a given restaurant (Kivela et al., 2OOO).

The HOLSERV is a scale developed by Mei et al. (I999) as a new instrument to measure service quality in the hotel industry. They concluded that service quality was represented by three dimensions in the hotel industry, relating to "employees", "tangibles" and "reliability", and the best predictor of overall service quality was the dimension referred to as "employees".

The TANGSERV is a scale for measuring tangible quality in food service industry. It captures ambient factors such as music and temperature; design factors such as location and seating arrangement; and product/service factors such as food presentation and food variety. One of the implications of TANGSERV for restaurant managers is to design their layout around the constructs of the measure in order to meet the expectations of patrons.

Kincaid et al. (2OIO) evaluated the usefulness of the TANGSERV (tangible quality) scale by examining the effect of tangible quality constructs on restaurant patrons' affect and 
behavioral intentions. They concluded that the food and service construct and accessibility construct of tangible quality exhibited positive impact on the affect towards restaurants, which in turn influenced re-patronage intention for restaurants.

The DINESCAPE is defined as the man-made physical and human surroundings in the dining area of upscale restaurants. The DINESCAPE includes six dimensions: facility aesthetics, lighting, ambience, layout, table settings, and service staff.

According to Booms and Bitner (1982) the servicescape of a hospitality firm had a significant impact on customer revisit intention and a restaurant's brand image. They argued that the physical environment of restaurants could be effectively utilized to strengthen the brand image of the company, to reposition the guest's perceptual mapping among competition, and to enhance directly their customer satisfaction with the service encounter. Nguyen and Leblanc (20O2) revealed that physical environment had a significantly positive impact on perceived corporate image by new clients from a life insurance company.

Brady and Cronin (2OOI) and Raajpoot (2002) found in four different service industries that customers listed the service environment as a consideration in their service quality evaluations. Their studies revealed three factors that influence perceived quality of the physical environment: ambient conditions, facility design, and social factors.

\section{Restaurant quality dimensions}

The delivery of high-quality service is a difficult task for a service provider because of the intangible nature of service. Therefore, a service firm needs standardized, systematic, and quantitative measurements to assess its performance. Thus, a specification of service quality should be identified because it helps managers and employees understand the components of service quality, sets training program standards and policies for employees to follow, and helps firms evaluate and control performance (Fu and Parks, 2OOI)

Previous studies on customer expectation and service-quality perception in the foodservice industry have revealed certain important attributes, such as low price, food quality, value for money, service, location, brand name, and image (Tam, Yung, 2003). More specifically, the fundamental factors that contribute to customer satisfaction in restaurants include the food, physical provision, the atmosphere and the service received during the meal experience (Johns and Pine, 20O2).

Food plays a pivotal role in the restaurant experience and its taste, presentation, textures, colors, temperature, freshness, nutritive value and smell are identified by restaurant guest as a important quality attributes. The portions size and menu variety are considered as determinants enhancing pleasure in the food experience (Kivela et al., 2OOO).

Service delivery is an integral part of a restaurant product, and employees' performance and attitude play a crucial role in the process. Employees in restaurant industry are of vital importance for restaurant organizations, as the organizations depend on their enthusiasm and capability to deliver products and services (Baum, Nickson, I998). Successful restaurants employ managers and employees who perform at a high level and work to accomplish the restaurant's goals. Brooks (2000) yielded research outcomes to show that $40-80 \%$ of customer satisfaction and customer loyalty depends on the relationship with the employees. Employees' satisfaction had a significant, positive effect on customer satisfaction (Bernhardt et al., 2000; Spinelli, Canavos, 2000; Wangenheim et al., 2007; Chi, Gursoy, 2009). Restaurant employee are expected to be competent, attentive, fast, friendly, helpful, prompt, 
Table 1. Literature Review of Restaurant Quality Dimensions

\begin{tabular}{|l|l|l|}
\hline Construct & Variable & Author \\
\hline Food quality & $\begin{array}{l}\text { tastiness of food, menu variety, nutrition, food } \\
\text { is served at the appropriate temperature, food } \\
\text { presentation is attractive, serving size, menu } \\
\text { design, healthy options, freshness }\end{array}$ & $\begin{array}{l}\text { Kivela et al. (2000); Namkung and Jang (2008), Raajpoot } \\
\text { (2002), Kivela et al. (1999); Koo et al. (1999); Law et al. } \\
\text { (2008); Mertanen (2007); Johns and Pine, (2002); Olsen, } \\
\text { (2002); Cortese (2003); Sulek and Hensley; (2004); } \\
\text { Péneau, et al, (2006) }\end{array}$ \\
\hline Service quality & $\begin{array}{l}\text { employees are always willing to help me, } \\
\text { employees have the knowledge to answer my } \\
\text { questions, the chain restaurant brand has my } \\
\text { best interests at heart, staff appearance, atten- } \\
\text { tive stuff, friendly dining managers. }\end{array}$ & $\begin{array}{l}\text { Parasuraman et al. (1988); Inbakaran, Reece (2000); Oh } \\
\text { (2000); Kivelä, Yiu Ha Chu, (2001); Kim et al. (2009); }\end{array}$ \\
\hline Chow et al, (2007)
\end{tabular}

empathetic, honest and responsible. All these qualities are integral part of assessing the quality of service staff.

Dining is more than eating out for a majority of guests who may not want to feel at home. They may seek a memorable experience away from home, and physical environment can play a critical role in creating that memorable experience. Facility aesthetics, ambience, lighting, table settings, layout, and service staff are elements of a physical environment that had a significant impact on customer revisit intention and a restaurant's brand image.

Perceived price fairness is a critical factor influencing customer satisfaction. Therefore, it is crucial to be in accordance with the quality in order to escape guests dissatisfaction, complaining, and bad WOM (Word-of-mouth) (Andaleeb and Conway, 2006).

By confirming the importance of the restaurant quality dimensions to customer satisfaction, these empirical studies have provided valuable insights into customer perceptions about the quality of service delivery. Even so, there is still a need for a better understanding of how customers perceive specific service encounters in restaurants.

\section{Conclusion}

The hospitality industry is a demanding sector that stresses the provision of high-level customer service and continuous quality improvement. Development of a clear picture of service quality in the hospitality industry context is important to more precisely identify the "whats" and "hows" of service-quality improvement, both in everyday and extraordinary contexts.

Numerous studies have dealt with the measurement of service quality in the hospitality industry. Perception of service quality is a result of the comparison of customer's expectations and actual performances so it is very important to use tools for measuring the service quality in order to identify gaps. Gržinić (2007) presented a detailed analysis of arguments that have contributed to a high positioning of the SERVQUAL model among the various ways to measure service quality. She claimed that hotel managers do not know the expectations of their guests because the dimensions of service quality they consider most important, do not match those that are most important for the clients, which is confirmed by the 
total SERVQUAL gap. Blesic, Romelic and Bradic (2009) found that guests are not satisfied with the hotel service, and that their expectations were higher (spa hotels of West Morava Region). Souza, Meira and Maske (2OI2) evaluated the perception and expectation of the quality of services provided by hotels in the city of Balneario Camboriu, Santa Catarina, using an adaptation of the SERVQUAL model and identified differences between the expected quality and perceived quality on most items evaluated.

As lifestyles change and dining out becomes more and more common place, customers desire new flavors, comfortable ambience and pleasant memories. What is more, they prefer an excellent overall dining experience. There are many factors that may influence customers' assessments of restaurant quality and restaurant operators should be aware each of them. They should pay attention to the key quality attributes that elicit customer satisfaction and enhance return visits in the restaurant business. Marinković, Senic and Dimitrovski (2OI3) concluded that food quality, service quality and ambience have significant effects on restaurant guests satisfaction. Liy and Jang (2009) suggested that food quality, service reliability and environmental cleanliness were three pivotal aspects to Chinese restaurants' success. More specifically, food safety and environmental cleanliness were prerequisites when customers chose a Chinese restaurant. Food quality (especially taste) and service quality (especially service reliability) were the key attributes for Chinese restaurants' success. Dining atmosphere, food authenticity and fair price were also significant contributors to customer satisfaction and behavioral intention. Kim and Moon (2009) examines the impact of customers' perceptions of the servicescape on pleasure-feeling and perceived service quality, and the effect of these two constructs on revisit intention. The results show that the direct relationship between the servicescape and revisit intention was found to be insignificant. Therefore, they suggested that the perception of the servicescape directly influences customer emotions and in turn indirectly affects their behavioral intentions. Longart (2OIO) founded a clear link between satisfaction with food and drink as a key driver of PWOM (positive word-of-mouth).

Oyewole (2OI3) founded that the criteria which African Americans use to evaluate service quality in all-you-can-eat Buffet restaurants are "freshness," "hygiene," "variety and reliability," and"value,". Ryu, Lee and Kim (2OI2) concluded that the quality of the physical environment, food, and service were significant determinants of restaurant image. Also, the quality of the physical environment and food were significant predictors of customer perceived value. The restaurant image was also found to be a significant antecedent of customer perceived value. In addition, the results reinforced that customer perceived value is indeed a significant determinant of customer satisfaction, and customer satisfaction is a significant predictor of behavioral intentions. Barber, Goodman and Goh (2OII) analyzed if a correlation exists between physical environment service quality attributes and repeat patronage. Results indicated decisions to return were based upon cleanliness attributes and are meaningful because they suggest the importance of continued education and establishing benchmark scores to track customer cleanliness perceptions in service organizations. Fu and Parks (2OOI) founded that friendly service and individual attention were more important factors than tangible aspects of service in influencing elderly customers' behavioral intentions. Ryu and Han (2OII) found that facility aesthetics, lighting, layout, and service staff had significant effects on disconfirmation. Moreover, disconfirmation exerted a direct influence on customer satisfaction and customer loyalty.

Guest satisfaction is essential indicator of a restaurants's overall performance, and restaurateurs should put effort in order to identify what determines it. When service does not meet 
a guest's expectations guests may seek for other solution. Satisfaction of users is not a static category. Instead, it changes dynamically in accordance with behaviour, wishes, needs and requirements of users of restaurant services.

\section{References}

Almanza, B. A., Jaffe, W., Lin, L. (I994). Use of the service attribute matrix to measure consumer satisfaction. Journal of Hospitality \& Tourism Research,I7(2), 63-75.

Andaleeb, S. S., Caskey, A. (2007). Satisfaction with food services: Insights from a college cafeteria. Journal of Foodservice Business Research IO (2), 5I-65.

Andaleeb, S.S., Conway, C. (2006). Customer satisfaction in the restaurant industry: An examination of the transaction-specific model. Journal of Services Marketing $2 \mathrm{O}$ (I), 3-II.

Barber, N., Goodman, R. J., Goh, B. K. (2OII). Restaurant consumers repeat patronage: A service quality concern. International Journal of Hospitality Management, 3O(2), 329-336.

Bernhardt, K.L., Donthu, N., Kennett, P.A. (200O). A longitudinal analysis of satisfaction and profitability. Journal of Business Research, 47 (2), I6I-I7I.

Berry, L. Lampo, S. (2004). Branding labour-intensive services. Business Strategy Review I5 (I), I8-25.

Bitner, M.J. Hubbert, A.R. (I994). Encounter satisfaction versus overall satisfaction versus quality, in Rust, R.T. and Oliver, R.L. (Eds), Service Quality: New Directions in Theory and Practice, Sage, New York, 72-84.

Blešic I., Tešanovic D., \& Psodorov Đ. (2OII). Consumer Satisfaction and Quality Management in the Hospitality Industry in South-East Europe, African Journal of Business Management 5(4), I388-I396.

Blešić, I., Romelić, J., Bradić, M. (2009). Applying a Modified SERVQUAL Model in the Evaluation of the Quality of Hotel Services, on the Example of the Western Morava Spa Zone, Journal of the Geographical Institute "Jovan Cvijić" SASA, 59(I), 93-IIO.

Bolton, L.E., Warlop, L., Alba, J. (2OO3). Consumer perceptions of price (Un)fairness. Journal of Consumer Research, 29 (4), 474-492.

Booms, B.H. Bitner, M.J. (1982). Marketing services by managing the environment, Cornell Hospitality Quarterly 23(I), 35-40.

Brady, M., Cronin, J., (2OOI). Some new thoughts on conceptualizing perceived service quality: a hierarchical approach. Journal of Marketing 65, 34-49.

Brooks, R.(2000). Why loyal employees and customers improve the bottom line, Journal of Quality and Participation 23 (2), 4O-44.

Chi, C.G., Gursoy, D. (2009). Employee satisfaction, customer satisfaction, and financial performance: an empirical examination, International Journal of Hospitality Management, 28 (2), 245-253.

Chow, H. S., Lau, V. P., Lo, W. C., Sha, Z., Yun, H. (2007). Service quality in restaurant operations in China: decision-and experiential-oriented perspectives. International Journal of Hospitality Management, 26(3), 698-7IO.

Chow, I.H., Lau, V.P., Lo, T.Y., Sha, Z.Yun, H. (2007). Service quality in restaurant operations in China: decision- and experiential-oriented perspectives, International Journal of Hospitality Management 26(3), 698-7IO.

Cobe, P. (2007). How to revive a tired décor: Creative ideas and practical tips to help perk up your interior. Restaurant Business, April, 26-32. 
Cortese, A. (2003). Fine dining? Just across the lobby: Some of the best new restaurants are popping up in hotels. Business Week, I3O-I3I.

Dabholkar, P.A., Shepherd, C.D., Thorpe, D.I. (2000). A comprehensive framework for service quality: an investigation of critical conceptual and measurement issues through a longitudinal study, Journal of Retailing, 76(2), I39-73.

Ekinci, Y., Riley, M. (I997). An examination of The SERVQUAL and LODGSERV Scales performance in the case of holiday makers' perception of resort hotel service quality: a pilot study. In: Proceedings of the 6th Annual Hospitality Research Conference. Oxford Brookes University, Oxford, UK, I64-I85.

Ekinci, Y., Riley, M. (1998). A critique of the issues and theoretical assumptions in service quality measurement in the lodging industrytime to move the goal-posts? International Journal of Hospitality Management, I7, 349-362.

Frochot, I., Hughes, H. (2000). Histoqual: the development of a historic houses assessment scale, Tourism Management, 2I, I57-I67.

Fu, Y. Y., Parks, S. C. (2OOI). The relationship between restaurant service quality and consumer loyalty among the elderly. Journal of Hospitality \& Tourism Research, 25(3), 32O-326.

Gržinić, J. (2007). Concepts of service quality measurement in hotel industry. Ekonomska misao i praksa, (I), 8I-98.

Gummesson, E., Brown, S.W., Edvardsson, B., Gustavson, B. (I99I). Service quality: a holistic view, Lexington Books, Lexington, MA, 3-22.

Heung, V. C. (2002). American theme restaurants: A study of consumer's perceptions of the important attributes in restaurant selection. Asia Pacific Journal of Tourism Research, 7(I), I9-28.

Heung, V. C., Wong, M. Y. (I997). Hotel service quality in Hong Kong: A study of tourists' expectations. Journal of Vacation Marketing, 3(3), 264-27I.

Iacobucci, D., Grayson, K.A., Ostrom, A.L. (1994). The calculus of service quality and customer satisfaction: theoretical and empirical differentiation and integration", in Swartz, T.W. (Ed.), Advances in Services Marketing and Management, Vol. 3, JAI Press, Greenwich, CT.

Jang, S., Namkung, Y. (2009). Perceived quality, emotions, and behavioral intentions: application of an extended Mehrabian-Russell model to restaurants. Journal of Business Research 62 (4), 45I-460.

Johns, N., Pine, R. (2002). Consumer behavior in the food service industry: a review. International Journal of Hospitality Management 2I, II9-I34.

Johnson, M.D., Anderson, E.W. and Fornell, C. (I995), Rational and adaptive performance expectations in a customer satisfaction framework, The Journal of Consumer Research, 2I(4), 695-707.

Kim, W. G., Ng, C. Y. N., Kim, Y. S. (2009). Influence of institutional DINESERV on customer satisfaction, return intention, and word-of-mouth. International Journal of Hospitality Management, 28(I), IO-I7.

Kincaid, C., Baloglu, S., Mao, Z., Busser, J. (2OIO). What really brings them back?: The impact of tangible quality on affect and intention for casual dining restaurant patrons. International Journal of Contemporary Hospitality Management, 22(2), 209-22O.

Kivelä, J. J., Chu, C. Y. H. (2OOI). Delivering quality service: Diagnosing favorable and unfavorable service encounters in restaurants. Journal of Hospitality \& Tourism Research, 25(3), 25I-27I. 
Kivela, J., Inbakaran, R., Reece, J. (2000). Consumer research in the restaurant environment. Part 3. Analysis, findings and conclusions. International Journal of Contemporary Hospitality Management I2 (I), I3-3O.

Knutson, B., Stevens, P., Wullaert, C., Patton, M., Yokoyama, F. (I990). LODGESERV: a service quality index for the lodging industry, Hospitality Research Journal, I4(2), 277-84.

Koo, L. C., Tao, F. K., Yeung, J. H. (I999). Preferential segmentation of restaurant attributes through conjoint analysis. International Journal of Contemporary Hospitality management, II(5), 242-253.

Kurtich, J., Eakin, G. (I993). Interior Architecture. Van Nostrand Reinhold, New York, NY.

Law, R., To, T., Goh, C. (2008). How do Mainland Chinese travelers choose restaurants in Hong Kong?: An exploratory study of individual visit scheme travelers and packaged travelers. International Journal of Hospitality Management, 27(3), 346-354.

Lin, I.Y. (20O4). Evaluating a servicescape: the effect of cognition and emotion. International Journal of Hospitality Management 23 (2), I63-I78.

Liu, Y., Jang, S. (2009). Perceptions of Chinese restaurants in the US: what affects customer satisfaction and behavioral intentions? International Journal of Hospitality Management, 28 (3), 338-348.

Lockyer, T. (2003). Hotel cleanliness-how do guests view it? Let us get specific. A New Zealand study. International Journal of Hospitality Management, 22(3), 297-305.

Longart, P. (2OIO). What drives word-of-mouth in restaurants?. International Journal of Contemporary Hospitality Management, 22(I), I2I-I28.

Luo, X., Homburg, C. (2007). Neglected Outcomes of Customer Satisfaction. Journal of Marketing, 7I(2), I33-I49.

Marinković, V., Senić, V., Dimitrovski, D. (20I3). Measuring Consumers' Attitudes Towards Service Quality In Restaurants, Themes Journal for Social Research (Teme Časopis za Društvene Nauke), (OI), 3I9-338.

Martínez-tur, V., Tordera, N., Peiró, J., Potocnik, K., (2OII). Linking Service Climate and Disconfirmation of Expectations as Predictors of Customer Satisfaction: A mCross-Level Study I, Journal of Applied Social Psychology, 4I(5), II89-I2I3.

Mattila, A. S. (2OOI). Emotional bonding and restaurant loyalty. The Cornell Hotel and Restaurant Administration Quarterly, 42(6), 73-79.

Mei, A. W. O., Dean, A. M., White, C. J. (I999). Analysing service quality in the hospitality industry. Managing Service Quality, 9(2), I36-I43.

Mok, C., Patton, M. E. (I999). Articles/Dimensionality of the Lodgserv Instrument: an Application to Measure Hotel Service Quality Expectations of Korean Tourists. Korean Journal of Hotel Administration, I(I), I-8.

Nam, J. H., Lee, T. J. (2OII). Foreign travelers' satisfaction with traditional Korean restaurants. International Journal of Hospitality Management, 3O(4), 982-989.

Namkung, Y. Jang, S. (2008). Are highly satisfied restaurant customers really different? A quality perception perspective, International Journal of Contemporary Hospitality Management, 2O(2), I42-55.

Nguyen, N., Leblanc, G. (20O2). Contact personnel, physical environment and the perceived corporate image of intangible services by new clients", International Journal of Service Industry Management, I3(3), 242-62.

Oh, H. (2000). Quality, value, and satisfaction: a practical viewpoint, The Cornell Hotel and Restaurant Administration Quarterly, 4I(3), 58-66. 
Olsen, S.O. (2002). Comparative evaluation and the relationship between quality, satisfaction, and repurchase loyalty. Journal of the Academy of Marketing Science 3O (3), 24O-249.

Oyewole, P. (20I3). The role of frequency of patronage and service quality of all-you-can-eat buffet restaurant: A perspective of socio-economic and demographic characteristics of African American consumers. International Journal of Hospitality Management, 34, 202-2I3.

Péneau, S., Hoehn, E., Roth, H.-R., Escher, F., Nuessli, J. (2006). Importance and consumer perception of freshness of apples. Food Quality and Preference, I7(I/2), 9-I9.

Pettijohn, L. S., Pettijohn, C. E., Luke, R. H. (I997). An evaluation of fast food restaurant satisfaction: determinants, competitive comparisons and impact on future patronage. Journal of Restaurant \& Foodservice Marketing, 2(3), 3-20.

$\mathrm{Qu}, \mathrm{H}$. (1997). Determinant factors and choice intention for Chinese restaurant dining: a multivariate approach. Journal of Restaurant \& Foodservice Marketing, 2(2), 35-49.

Raajpoot, N.A. (2002). "TANGSERV: a multiple item scale for measuring tangible quality in foodservice industry”, Journal of Foodservice Business Research, 5(2), IO9-27.

Rust, R.T. and Oliver, R.L. (1994). Service Quality: Insights and Managerial Implications from the Frontier, Sage, Thousand Oaks, CA.

Ryu, K., Han, H. (2OII). New or repeat customers: How does physical environment influence their restaurant experience? International Journal of Hospitality Management, 30(3), 599-6II.

Ryu, K., Jang, S. (2007). The effect of environmental perceptions on behavioral intentions through emotions: the case of upscale restaurants, Journal of Hospitality and Tourism Research, 3I (I), 56-72.

Ryu, K., Jang, S. (2008). DINESCAPE: a scale for customers' perception of dining environments Journal of Foodservice Business Research, II (I), 2-22.

Ryu, K., Lee, H. R., Kim, W. G. (2OI2). The influence of the quality of the physical environment, food, and service on restaurant image, customer perceived value, customer satisfaction, and behavioral intentions. International Journal of Contemporary Hospitality Management, 24(2), 200-223.

Spinelli, M.A., Canavos, G.C. (2000). Investigating the relationship between employee satisfaction and guest satisfaction, Cornell Hotel and Restaurant Administration Quarterly, 4I, 29-33.

Stevens, P., Knutson, B., Patton, M. (I995). "DINESERV: a tool for measuring service quality in restaurant", The Cornell Hotel and Restaurant Administration Quarterly, 36(2), 56-60.

Sulek, J.M., Hensley, R.L. (2004). The relative importance of food, atmosphere, and fairness of wait. Cornell Hotel and Restaurant Administration Quarterly 45 (3), 235-247.

Sureshchander, G.S., Rajendran, C. and Anatharaman, R.N. (2OO2). The relationship between service quality and customer satisfaction: a factor-specific approach, Journal of Services Marketing, I6(4), 363-79.

Tam, W.Y., Yung, N.L.A. (2003). Managing customer for value in catering industry (fast food) in Hong Kong. MBA thesis, The Chinese University of Hong Kong.

Wangenheim, F.V., Evanschitzky, H., Wunderlich, M.(2007). Does the employee-customer satisfaction link hold for all employee groups? Journal of Business Research, 60 (7), 690697.

Zeithaml, V.A. (1987). Defining and Relating Price, Perceived Quality, and Perceived Value, Marketing Science Institute, Cambridge, MA.

Zeithaml, V.A., Parasuraman, A., Berry, L. (I990). Delivering Quality Service: Balancing Customer Perceptions and Expectations The Free Press, New York, NY. 